\title{
Silicon Solar Cells with Front Hetero-Contact and Aluminum Alloy Back Junction
}

Conference Paper NREL/CP-520-42566

May 2008

\section{Preprint}

H.-C. Yuan, M.R. Page, E. Iwaniczko, Y. Xu, L. Roybal, Q. Wang, and H.M. Branz National Renewable Energy Laboratory

D.L. Meier

Suniva, Inc.

Presented at the 33rd IEEE Photovoltaic Specialists Conference San Diego, California May 11-16, 2008 


\section{NOTICE}

The submitted manuscript has been offered by an employee of the Midwest Research Institute (MRI), a contractor of the US Government under Contract No. DE-AC36-99G010337. Accordingly, the US Government and MRI retain a nonexclusive royalty-free license to publish or reproduce the published form of this contribution, or allow others to do so, for US Government purposes.

This report was prepared as an account of work sponsored by an agency of the United States government. Neither the United States government nor any agency thereof, nor any of their employees, makes any warranty, express or implied, or assumes any legal liability or responsibility for the accuracy, completeness, or usefulness of any information, apparatus, product, or process disclosed, or represents that its use would not infringe privately owned rights. Reference herein to any specific commercial product, process, or service by trade name, trademark, manufacturer, or otherwise does not necessarily constitute or imply its endorsement, recommendation, or favoring by the United States government or any agency thereof. The views and opinions of authors expressed herein do not necessarily state or reflect those of the United States government or any agency thereof.

Available electronically at http://www.osti.gov/bridge

Available for a processing fee to U.S. Department of Energy and its contractors, in paper, from:

U.S. Department of Energy

Office of Scientific and Technical Information

P.O. Box 62

Oak Ridge, TN 37831-0062

phone: 865.576 .8401

fax: 865.576 .5728

email: mailto:reports@adonis.osti.gov

Available for sale to the public, in paper, from:

U.S. Department of Commerce

National Technical Information Service

5285 Port Royal Road

Springfield, VA 22161

phone: 800.553 .6847

fax: 703.605.6900

email: orders@ntis.fedworld.gov

online ordering: http://www.ntis.gov/ordering.htm 


\title{
SILICON SOLAR CELLS WITH FRONT HETERO-CONTACT AND ALUMINUM ALLOY BACK JUNCTION
}

\author{
Hao-Chih Yuan, Matthew R. Page, Eugene Iwaniczko, Yueqin Xu, Lorenzo Roybal, Qi Wang, Howard M. Branz, and \\ Daniel L. Meier ${ }^{*}$ \\ National Renewable Energy Laboratory (NREL), 1617 Cole Blvd., Golden, CO 80401, USA \\ "Present address: Suniva Inc., 75 Fifth St. NW, Suite 215, Atlanta, GA 30308, USA
}

\begin{abstract}
We prototype an alternative n-type monocrystalline silicon (c-Si) solar cell structure that utilizes an n/i-type hydrogenated amorphous silicon (a-Si:H) front heterocontact and a back $p-n$ junction formed by alloying aluminum (Al) with the n-type Si wafer. Such a structure combines a conventional high-throughput $\mathrm{Al}-\mathrm{Si}$ alloying process with excellent front surface passivation provided by a-Si:H. A key process consideration is to preserve the clean $\mathrm{c}-\mathrm{Si}$ front surface through the high-temperature alloying, so there will be effective a-Si:H passivation. From cell simulations, we estimate a front SRV of $10-50 \mathrm{~cm} / \mathrm{sec}$ has been achieved in our process. The best prototype $1 \times 1$ $\mathrm{cm}^{2}$ cell with planar front surface and single anti-reflection (AR) coating layer has demonstrated a confirmed conversion efficiency of $13.5 \%, V_{\text {oc }}$ of $604.7 \mathrm{mV}$, and fill factor (FF) of $79.9 \%$. Processes for further efficiency improvements are described.
\end{abstract}

\section{INTRODUCTION}

Silicon solar cells with a heterojunction front emitter made of thin layers of hydrogenated amorphous silicon (a-Si:H) and an a-Si:H back hetero-contact have demonstrated efficiency higher than $22 \%$ [1] and 19\% [2] on high-quality $n$ - and $p$-type monocrystalline silicon (c-Si), respectively. The a-Si:H has been deposited by various chemical vapor deposition (CVD) techniques and here in NREL we have focused mostly on developing and optimizing a-Si:H thin film deposited by hot-wire chemical vapor deposition (HWCVD). One of the key advantages of the a-Si:H/c-Si hetero-interface is the low surface recombination velocity (SRV) and high $\mathrm{V}_{\text {oc }}$ resulting from the low interface state density. SRV below $20 \mathrm{~cm} / \mathrm{sec}$ [3] and $V_{o c}$ above 710 and $675 \mathrm{mV}[2,4,5]$ have been consistently produced at NREL by HWCVD of doublesided Si hetero-junction (SHJ) cells on n- and p-type c-Si, respectively. NREL's cells use HWCVD instead of plasmaenhanced CVD to eliminate the potential ion damage to the high-quality c-Si wafer surface during deposition.

In this paper we report an alternative cell structure on ntype c-Si that combines (n/i)-a-Si as the front surface passivation and electrical contact, with alloyed aluminum (Al) back junction and contacting. The cell is illustrated schematically in Fig. 1. The back p-n junction emitter is formed by depositing $\mathrm{Al}$, followed by high-temperature alloying. The Al-alloyed back junction has a far higher back SRV compared with the double-sided a-Si heterojunction emitter used in the SHJ cell, but it is a simple structure and can be manufactured cost effectively. Cell efficiency higher than $18 \%$ has been reported with $\mathrm{Al}$ alloy back junction and diffused front surface field [6]. In this study we discuss our first attempts to incorporating the excellent front surface passivation by thin (n/i)-a-Si heterocontact with an Al-Si back junction. The combination of high-temperature alloying followed by low-temperature aSi deposition presents a unique challenge: it is essential to preserve the clean $\mathrm{c}-\mathrm{Si}$ front surface until a-Si:H passivation in order to achieve the desired low front SRV. We will discuss in the paper the effect of different surface preparations on front SRV. We will also analyze our current process to understand the possible limiting factors for $V_{o c}$ and cell efficiency.

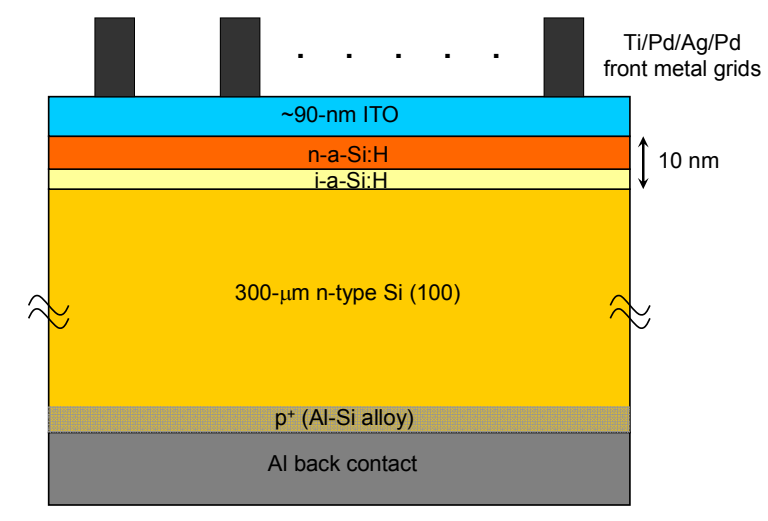

Fig. 1: Schematic cross section of a cell with a-Si:H front hetero-contact and Al-Si alloy back junction. 


\section{DEVICE FABRICATION}

Phosphorus-doped, n-type double-side polished $\mathrm{Si}$ (100) float zone substrates with resistivity of $1.2 \Omega-\mathrm{cm}$ and thickness of $300 \mu \mathrm{m}$ were cleaned by the RCA-1, dilute $\mathrm{HF}$ dip, and RCA-2 cleaning processes, in sequence. Samples in this study were not texture etched. One of the essential tasks is to preserve a clean c-Si surface throughout the high-temperature alloying process. We tested three different surface preparations made immediately after the chemical cleaning. These approaches were (1) remove the chemical oxide left by the RCA-2 cleaning and then grow a layer of thermal oxide $(\sim 76 \mathrm{~nm})$ at $1000^{\circ} \mathrm{C}$ in $\mathrm{O}_{2}$ ambient; (2) leave the surface covered with the chemical oxide; and (3) cover the front surface with spin-on-glass (SOG) (Filmtronics 700B) and densify the SOG layer at $425^{\circ} \mathrm{C}$ for $60 \mathrm{~min}$ to produce a glass layer of $\sim 200 \mathrm{~nm}$. After soaking the back side of the samples with dilute HF to remove the oxide and ensure a good Al-to-Si contact, we then deposited the back side with 3- $\mu \mathrm{m}$ of Al by e-beam evaporation. Al-Si alloying was performed in conventional tube furnace at $900^{\circ} \mathrm{C}$ for 30 min. A Al-doped back surface field ( $\mathrm{p}^{+}$layer) of about half of the deposited Al thickness will be formed at this alloying temperature [7].

Thin layers of intrinsic and n-type doped a-Si:H were subsequently deposited on the front surface by HWCVD after a front-surface-only dilute HF soaking removes the front oxide or glass. The intrinsic and n-type a-Si layers were deposited at a substrate temperature of $100^{\circ} \mathrm{C}$ with $\mathrm{SiH}_{4}$ feedstock gas and at $160^{\circ} \mathrm{C}$ from a mixture of $\mathrm{SiH}_{4}$, $\mathrm{H}_{2}$, and $\mathrm{PH}_{3}$ gases, respectively. Conditions for NREL HWCVD hetero-contact formation are described elsewhere [8]. The combined thickness of the $\mathrm{i}$ - and $\mathrm{n}$ layers of a-Si:H is $10 \mathrm{~nm}$. A 93-nm ITO was then evaporated on the front to provide good electrical contact to the front grid and serve as an anti-reflection (AR) coating. The front metal grid consists of 50/60/4000/60nm-thick $\mathrm{Ti} / \mathrm{Pd} / \mathrm{Ag} / \mathrm{Pd}$ stack was evaporated through a shadow mask. Shadowing by the front grid is approximately $5 \%$. Finally, cells were isolated by saw dicing into $1 \times 1 \mathrm{~cm}^{2}$ areas.

TABLE I: Summary of Suns- $V_{\text {oc }}$ and IQE on cells with different surface preparation before a-Si:H deposition.

\begin{tabular}{|c|c|c|c|}
\hline $\begin{array}{c}\text { Front surface } \\
\text { preparation }\end{array}$ & $\begin{array}{c}\text { Thermal } \\
\text { oxide }\end{array}$ & $\begin{array}{c}\text { Chemical } \\
\text { oxide }\end{array}$ & SOG \\
\hline Suns-Voc $(\mathrm{mV})$ & 617 & 611 & 548 \\
\hline IQE at $700 \mathrm{~nm} \mathrm{( \% )}$ & 83.4 & 77.7 & ---- \\
\hline
\end{tabular}

\section{RESULTS}

Table I summarizes the Suns- $V_{\text {oc }}$ measurement prediction of 1 Sun voltage (before dicing) [9] and the 700$\mathrm{nm}$ internal quantum efficiency (IQE) on completed cells with different front surface preparations. The cell protected by a thermal oxide on front side until the a-Si deposition shows the highest Suns $-V_{\text {oc }}$ whereas the cell with SOG shows the lowest. This suggests that the thermal oxide works best to preserve the cleanliness of the $\mathrm{c}$-Si front surface through the high-temperature $\mathrm{Al}-\mathrm{Si}$ alloying. The application of SOG is even worse than the case of simply having the thin chemical oxide on the surface. We suspect that SOG might have introduced impurities on the front surface which were driven into the c-Si during the hightemperature alloying. Impurity contamination can result in higher defect state density, lower carrier lifetime, and lower Suns- $V_{\text {oc }}$, as observed.

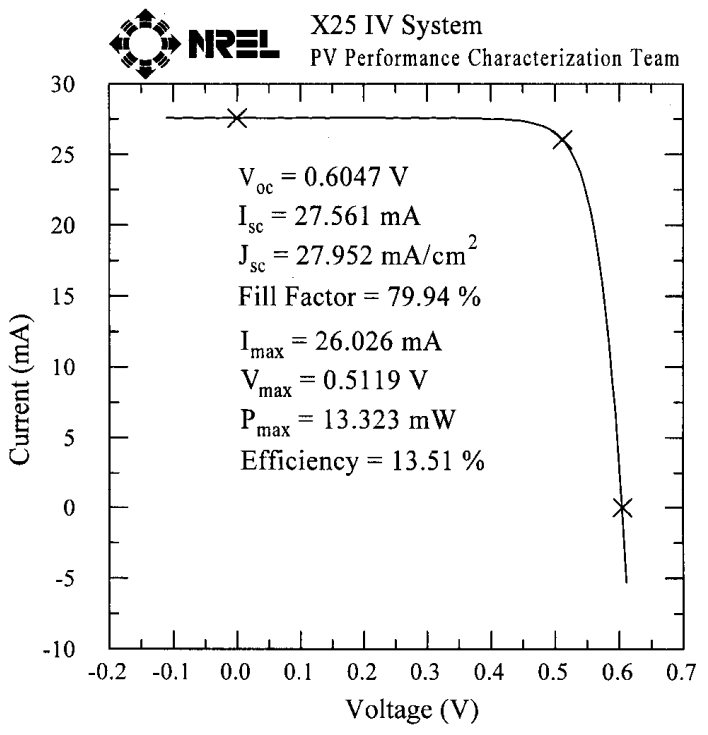

Fig. 2: Certified lighted I-V on n-type c-Si cell with an a-Si:H front hetero-contact and $\mathrm{Al}-\mathrm{Si}$ back junction.

Figure 2 presents the light current-voltage (I-V) curve, as measured by the independent Device Performance Section at NREL, on our $1 \times 1-\mathrm{cm}^{2}$ cell with thermal oxide protection of the front side until a-Si:H deposition. This untextured cell has a $\mathrm{V}_{\mathrm{oc}}$ of $604.7 \mathrm{mV}, \mathrm{J}_{\mathrm{sc}}$ of 27.95 $\mathrm{mA} / \mathrm{cm}^{2}$, FF of $79.94 \%$, and efficiency of $13.51 \%$. A roughly $10-m V V_{\text {oc }}$ drop compared with the Suns-Voc in Table $\mathrm{I}$ is likely due to recombination centers at the saw- 
damaged edges. Reflectance (R), external QE (EQE), and IQE results from the same cell are shown in Fig. 3. The positive slope of the IQE between the 600 and 1000-nm wavelength clearly indicates a back $p-n$ junction structure. The fall of IQE below 600-nm indicates excessive absorption by the front a-Si:H and ITO layers.

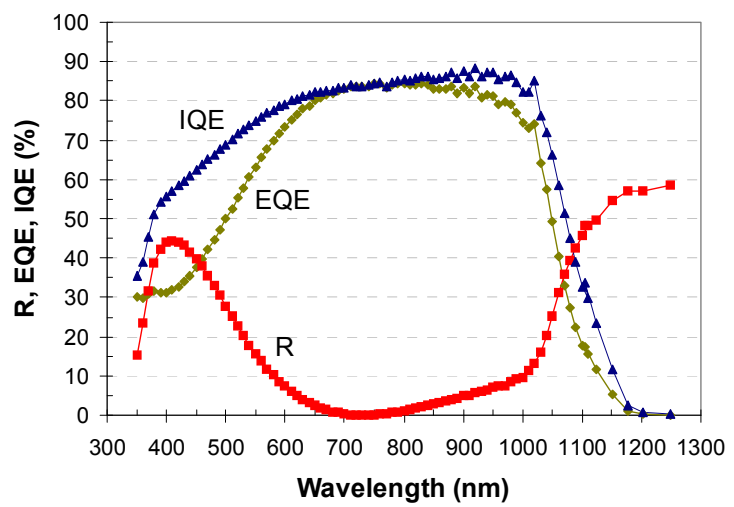

Fig. 3: R, EQE, and IQE results on cell with thermal oxide on front surface before a-Si deposition.

\section{DISCUSSION}

Simulations using PC1D were performed to estimate the front SRV and the effective base wafer minority carrier diffusion length $(\mathrm{L})$ on our cells. SRV on the Al-Si back surface is believed to be very high and was set to $10^{7}$ $\mathrm{cm} / \mathrm{sec}$ [10]. Figure 4 shows the relationships between IQE at 700-nm wavelength and the front SRV for a family of curves representing different values of $L$ ranging from 300 (bottom curve) to $700 \mu \mathrm{m}$ (top curve), in 50- $\mathrm{mm}$ intervals. The measured IQE from cells covered by thermal oxide and chemical oxide until front $\mathrm{a}-\mathrm{Si}$ deposition are indicated by the horizontal lines. The simulation suggests that the finished cells have $L$ better than $450 \mu \mathrm{m}$. Although a definitive front SRV cannot be determined, it appears that front SRV is between 10 and $50 \mathrm{~cm} / \mathrm{sec}$ on the cell with high-quality thermal oxide coverage until a-Si deposition. Thermal oxide has effectively preserved the clean c-Si surface throughout the high-temperature Al-Si alloying process: the front SRV on the finished cell is close to what we have obtained on lowtemperature processed double-sided SHJ cells $<20$ $\mathrm{cm} / \mathrm{sec}[3])$. Assuming that $L$ is comparable, the cell with chemical oxide coverage must have a front SRV more than twice as high as the cell with the thermal oxide. From this analysis, we can conclude that chemical oxide falls short on preserving the clean surface for a-Si passivation

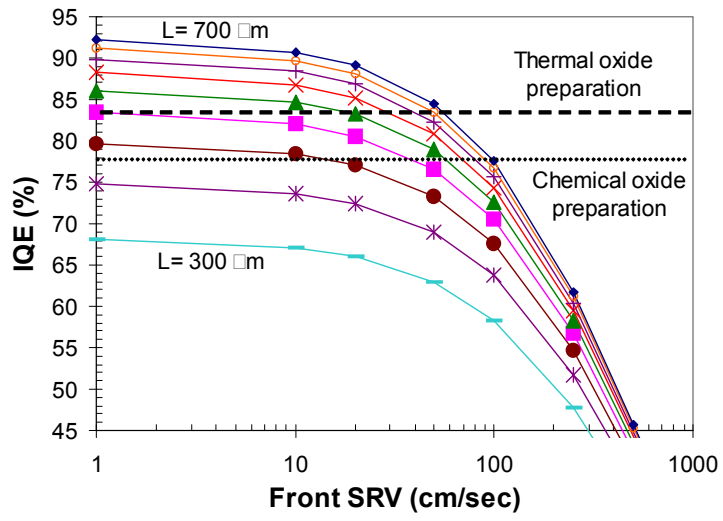

Fig. 4: Simulated IQE at $700 \mathrm{~nm}$. Curves from bottom to top have base diffusion lengths from 300 to $700 \mu \mathrm{m}$ in 50- $\mu \mathrm{m}$ intervals. Dashed and dotted lines indicate the IQE from cells with thermal oxide and chemical oxide protected front sides before a-Si:H deposition.

and a thermal oxidation process is preferred for the best cell performance.

Several improvements could be implemented to improve the cell performance. First, a textured surface may further increase the effectiveness of light trapping. Second, a better cell isolation technique or larger cell area may alleviate the impact on $V_{o c}$ from the damaged cell edges. Finally, a highly non-uniform appearance of the back surface after Al-Si alloying is often observed in our cells. It has been reported that non-uniformity and poor back-surface fields are obtain when a slow temperature ramp rate in a conventional tube furnace is used for $\mathrm{Al}-\mathrm{Si}$ alloying [11]. This problem likely extends to our Al backjunction processing. A widely implemented rapid thermal process or beltline furnace with a fast temperature ramp rate can likely achieve a more uniform $\mathrm{Al}-\mathrm{Si}$ alloy region and improve the junction quality.

\section{CONCLUSION}

We have demonstrated an alternative $\mathrm{c}$-Si solar cell structure with front a-Si:H hetero-contact and an $\mathrm{Al}-\mathrm{Si}$ alloy back junction. We have found that a protective layer of quality thermal oxide can provide a clean Si surface for a-Si:H passivation. By comparing the IQE from measurement results and simulation from PC1D, the corresponding front SRV is estimated to be between 10 and $50 \mathrm{~cm} / \mathrm{sec}$, close to what we have obtained on double-sided SHJ cells. The best of these prototype cells has a $\mathrm{V}_{\text {oc }}$ of $604.7 \mathrm{mV}$ and efficiency of $13.5 \%$, with an excellent FF of $79.9 \%$. This cell structure can potentially 
be manufactured cost-effectively and further process improvements should lead to better performance than what is reported here.

\section{ACKNOWLEDGEMENT}

The authors thank Anna Duda, Russell Bauer, and Tom Moriarty for their device processing and characterization assistance. This work was supported by the U.S. Department of Energy under Contact No. DE-AC3699G010337 with the National Renewable Energy Laboratory.

\section{REFERENCE}

[1] Y. Tsunomura, Y. Yoshimine, M. Taguchi, T. Kinoshita, H. Kanno, H. Sakata, E. Maruyama, and M. Tanaka, "22\%-efficiency HIT solar cell," Technical Digest of the International PVSEC-17, Fukuoka, 2007, pp. 387-390.

[2] Q. Wang, M. R. Page, E. Iwaniczko, Y. Xu, L. Robal, R. Bauer, B. To, H.-C. Yuan, A. Duda, and Y. F. Yan, "Crystal Silicon heterojunction solar cells by hot-wire CVD," Proc. of the $33^{\text {rd }}$ IEEE PVSC, San Diego, CA, 2008, this volume.

[3] D. L. Meier, M. R. Page, E. Iwaniczko, Y. Xu, Q. Wang, and H. M. Branz, "Determination of surface recombination velocities for thermal oxide and amorphous silicon on float zone silicon," Proc. of the $17^{\text {th }}$ Workshop on Crystalline Silicon Solar Cells and Modules, Vail, CO, 2007, pp. 214-217.

[4] M. R. Page, E. Iwaniczko, Y. Xu, Q. Wang, Y. Yan, L. Roybal, H. M. Branz, and T. H. Wang, "Well passivated a-Si:H back contacts for double- heterojunction silicon solar cells," Proc. of the $4^{\text {th }}$ IEEE WCPEC, Hawaii, 2006, pp. 1485-1488.

[5] T. H. Wang, E. Iwaniczko, M. R. Page, Q. Wang, Y. Xu, Y. Yan, D. Levi, L. Roybal, R. Bauer, and H. M. Branz, "High-efficiency silicon heterojunction solar cells by HWCVD," Proc. of the $4^{\text {th }}$ IEEE WCPEC, Hawaii, 2006, pp. 1439-1442.

[6] C. Schmiga, A. Froitzheim, M. Ghosh, A. Metz, J. Schmidt, and R. Brendel, "Solar cell on n-type silicon materials with screen-printed rear aluminum- $\mathrm{p}^{+}$ emitter," Proc. of the $20^{\text {th }}$ EU PVSEC, Barcelona, 2005, pp. 918-921.

[7] J. del Alamo, J. Eguren, and A. Luque, "Operating limits of Al-alloyed high-low junction for BSF solar cells," Solid-State Electronics, vol. 24, pp. 415-520, 1981.

[8] M. R. Page, E. Iwaniczko, Q. Wang, D. H. Levi, Y. Yan, H. M. Branz, V. Yelundur, A. Rohatgi, and T. H. Wang, "Progress in silicon heterojunction devices by hot-wire CVD," $14^{\text {th }}$ Workshop on c-Silicon, Winter Park, CO, 2004, pp. 246-250.

[9] R. A. Sinton, and A. Cuevas, "A quasi-steady-state open-circuit voltage method for solar cell characterization," Proc. of the $16^{\text {th }}$ EU PVSEC, Glasgow, UK, 2000, pp. 1152-1155.

[10] A. Cuevas, P. A. Basore, G. Giroult-Matlakowski, and C. Dubois, "Surface recombination velocity and energy bandgap narrowing of highly doped n-type silicon," Proc. of the $13^{\text {th }}$ EU PVSEC, Nice, France, 1995, pp. 337-342.

[11] S. Narasimha, A. Rohatgi, and A. W. Weeber, "An optimized rapid aluminum back surface field technique for silicon solar cells," IEEE Trans. Electron Devices, vol. 46, pp. 1363-1370, 1999. 


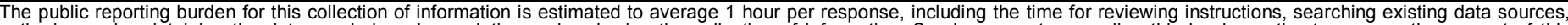

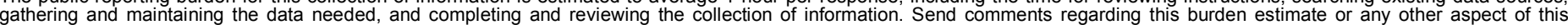

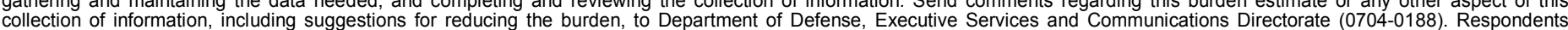

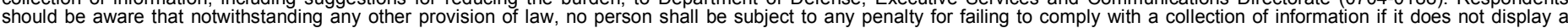

should be aware that notwithstandin

PLEASE DO NOT RETURN YOUR FORM TO THE ABOVE ORGANIZATION.

\section{REPORT DATE (DD-MM-YYYY) May 2008 \\ 2. REPORT TYPE Conference Paper}

4. TITLE AND SUBTITLE

Silicon Solar Cells with Front Hetero-Contact and Aluminum Alloy Back Junction: Preprint
3. DATES COVERED (From - To)

11-16 May 2008

5a. CONTRACT NUMBER

DE-AC36-99-G010337

5b. GRANT NUMBER

5c. PROGRAM ELEMENT NUMBER

5d. PROJECT NUMBER

NREL-CP-520-42566

5e. TASK NUMBER

PVA74101

5f. WORK UNIT NUMBER

7. PERFORMING ORGANIZATION NAME(S) AND ADDRESS(ES)

National Renewable Energy Laboratory

1617 Cole Blvd.

8. PERFORMING ORGANIZATION REPORT NUMBER

Golden, CO 80401-3393

NREL-CP-520-42566

9. SPONSORING/MONITORING AGENCY NAME(S) AND ADDRESS(ES)

10. SPONSOR/MONITOR'S ACRONYM(S) NREL

11. SPONSORING/MONITORING AGENCY REPORT NUMBER

12. DISTRIBUTION AVAILABILITY STATEMENT

National Technical Information Service

U.S. Department of Commerce

5285 Port Royal Road

Springfield, VA 22161

\section{SUPPLEMENTARY NOTES}

\section{ABSTRACT (Maximum 200 Words)}

We prototype an alternative n-type monocrystalline silicon (c-Si) solar cell structure that utilizes an n/i-type hydrogenated amorphous silicon (a-Si:H) front hetero-contact and a back $\mathrm{p}-\mathrm{n}$ junction formed by alloying aluminum (Al) with the n-type Si wafer. Such a structure combines a conventional high-throughput Al-Si alloying process with excellent front surface passivation provided by a-Si:H. A key process consideration is to preserve the clean c-Si front surface through the high-temperature alloying, so there will be effective a-Si:H passivation. From cell simulations, we estimate a front SRV of $10-50 \mathrm{~cm} / \mathrm{sec}$ has been achieved in our process. The best prototype $1 \times 1 \mathrm{~cm} 2 \mathrm{cell}$ with planar front surface and single anti-reflection (AR) coating layer has demonstrated a confirmed conversion efficiency of $13.5 \%$, Voc of $604.7 \mathrm{mV}$, and fill factor (FF) of $79.9 \%$. Processes for further efficiency improvements are described.

15. SUBJECT TERMS

PV; solar cells; hetero-contact; n-type; amorphous silicon; monocrystalline silicon; anti-reflection coating; efficiency;

16. SECURITY CLASSIFICATION OF:
\begin{tabular}{l|l|l|}
\hline $\begin{array}{l}\text { a. REPORT } \\
\text { Unclassified }\end{array}$ & $\begin{array}{l}\text { b. ABSTRACT } \\
\text { Unclassified }\end{array}$ & $\begin{array}{l}\text { c. THIS PAGE } \\
\text { Unclassified }\end{array}$ \\
\hline
\end{tabular}

\begin{tabular}{|c|c|}
\hline $\begin{array}{l}\text { 17. LIMITATION } \\
\text { OF ABSTRACT }\end{array}$ & $\begin{array}{l}\text { 18. NUMBER } \\
\text { OF PAGES }\end{array}$ \\
\hline UL & \\
\hline
\end{tabular}

19a. NAME OF RESPONSIBLE PERSON

19b. TELEPHONE NUMBER (Include area code) 